\title{
LTC Vacuum Blasting Machine (Metal): Baseline Report; Summary
}

\author{
Topical Report \\ July 31, 1997 \\ OSTI
}

RECEIVED

FFR 201998

\section{9}

Work Performed Under Contract No.: DE-FC21-95MC32260

For

U.S. Department of Energy

Office of Environmental Management

Office of Technology Development

1000 Independence Avenue

Washington, DC 20585
U.S. Department of Energy

Office of Fossil Energy

Federal Energy Technology Center

Morgantown Site

P.O. Box 880

Morgantown, West Virginia 26507-0880

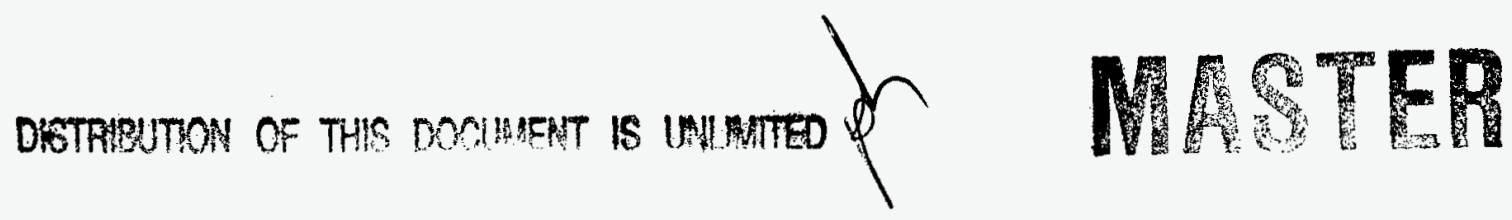

By

Operating Engineers National Hazmat Program

250 Airport Circle

Beaver, West Virginia 25813 


\section{Disclaimer}

This report was prepared as an account of work sponsored by an agency of the United States Government. Neither the United States Government nor any agency thereof, nor any of their employees, makes any warranty, express or implied, or assumes any legal liability or responsibility for the accuracy, completeness, or usefulness of any information, apparatus, product, or process disclosed, or represents that its use would not infringe privately owned rights. Reference herein to any specific commercial product, process, or service by trade name, trademark, manufacturer, or otherwise does not necessarily constitute or imply its endorsement, recommendation, or favoring by the United States Government or any agency thereof. The views and opinions of authors expressed herein do not necessarily state or reflect those of the United States Government or any agency thereof. 


\section{LTC COATING REMOVAL SYSTEM \\ HUMAN FACTORS ASSESSMENT - BASELINE}

\section{SECTION 1 - SUMMARY}

\section{Technology Description}

The LTC coating removal system consists of several hand tools such as a Roto Peen scaler and a needlegun. They are designed to remove coatings from steel, concrete, brick, and wood. These are used with the LTC PTC-6 vacuum system to capture dust and debris as removal of the coating takes place.

The PTC- 6 is a vacuum system designed to be used with surface decontamination equipment. Dust and debris are captured by a high efficiency particulate filter (HEPA) vacuum system that deposits the waste directly into an on-board 23-gallon waste drum. The PTC-6 utilizes compressed air delivered from a source via an air hose connected to the air inlet to drive the hand held power tools. The control panel regulates the air pressure delivered to the tool. A separate compressed air flow powers the vacuum generator. The vacuum hoses connect the power tools to the dust chamber, returning paint chips and dust from the surface. A third compressed air flow is used to clean filters by pulsing air through a pipe with slots. The blasts of air shake dust and debris from the filter fabric.

\section{Key Results}

The safety and health evaluation during the testing demonstration focused on two main areas of exposure: dust and noise. Dust exposure was minimal, but noise exposure was significant. Further testing for each exposure is recommended because of the open environment where the testing demonstration took place. It is feasible that the dust and noise levels will be higher in an enclosed operating environment of different construction. In addition, other areas of concern found were arm-hand vibration, whole-body vibration, ergonomics, heat stress, tripping hazards, electrical hazards, machine guarding, and lockout/tagout.

\section{SECTION 2 - HEALTH AND SAFETY EVALUATION}

\section{General Safety and Health Concerns}

Safety and health issues of concern with the LTC vacuum blasting machine included tripping hazards, electrical hazards, rotating machinery, lockout/tagout, heat stress, ergonomics, armhand vibration, whole-body vibration, noise, dust, and communication.

\section{Industrial Hygiene Monitoring}

During the testing demonstration, sampling was conducted for dust and noise. In addition, the wet-bulb globe temperature was monitored and observational evaluation was conducted for ergonomics and arm-hand vibration and wholebody vibration.

Ergonomically there is potential for muscle/back stress and/or injury to the knees. Arm-hand vibration was not quantitatively measured, but it was readily apparent that there was exposure to arm-hand vibration that could potentially cause health problems such as Raynaud's syndrome. Whole-body vibration was also apparent due to vibration of the floor in the work area.

Heat stress was monitored using wet-bulb globe measurements and worker physiological measurements such as blood pressure, pulse, and temperature and work/rest regimen 
recommendations were made in accordance with ACGIH recommendations.

Personal air sampling was conducted on the equipment operators. Personal sampling results were below allowable levels. Noise monitoring resulted in a dose of $810.69 \%$ or an 8-hour TWA of $105.1 \mathrm{dBA}$ and $1871.96 \%$ or an 8-hour TWA of $111.1 \mathrm{dBA}$. This exceeds the OSHA action level of $85 \mathrm{ABA}$ and the permissible exposure of limit $90 \mathrm{dBA}$. A hearing conservation program will be essential for anyone working with or around this equipment.

\section{Human Factors Interface}

Due to problems associated with the operator's size and health, he could not be dressed out in PPE. The technology needs to be evaluated for operator interface with the appropriate lat least level C) PPE including a full face air-purifying respirator.

\section{SECTION 3 - TECHNOLOGY APPLICABILITY}

On observation the technology did not deposit much visible dust into the atmosphere and air monitoring did not evidence an excessive dust level. There was some larger debris left on the surface at the sides of the scabbling head.

The metal descaling system will need to be torn down to be decontaminated. This will not necessarily guarantee that decontamination for alpha will be complete. It will be difficult to survey for alpha contamination due to all of the small spaces inherent in the equipment that are hard to reach with a probe. According to the technology representative, many parts, such as the hoses and brushes may be considered consumables.

\section{SECTION 4 - REGULATORY/POLICY ISSUES}

The site safety and health personnel where the LTC coating removal technology is being used need to be concerned with safety and health regulations applicable to the issues discussed above. Regulations that will apply may include but not be limited to the following areas: housekeeping, electrical, hand and power tools, machine guarding, lockout/tagout, toxic and hazardous substances, noise, respiratory protection, PPE, HAZCOM, HAZWOPER, and arm-hand and whole-body vibration.

\section{SECTION 5 - OPERATIONAL CONSIDERATIONS \& RECOMMENDATIONS}

Recommendations for improved worker safety and health include good housekeeping, ergonomic training and awareness, a clamping system for vacuum hoses, guarding all moving parts, assuring proper vacuum adjustment for adequate air flow, and engineering, administrative, and/or hearing protection be used for compliance with the OSHA noise standard.

Since Level A or Level B PPE may be required depending on the contaminants involved, it is recommended that the human factors interface for these levels of protection be conducted.

\footnotetext{
Research supported by the U.S. Department of Energy's Federal Energy Technology Center, under cooperative agreement DE-FC21-95MC32260 with the Operating Engineers National HAZMAT Program, 250 Airport Circle, Beaver, WW 25813, phone 304-253-8674, fax 304-253-7758. This report was prepared with the support of the US DOE; however, any opinions, findings, conclusions, or recommendations expressed herein are those of the author(s) and do not necessarily reflect the views of the DOE.
} 


\section{M98002035}

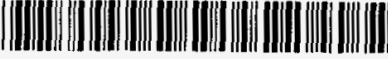

Report Number (14) DOE/mC/32260--5830

Jubl. Date (11)

19970731

sponsor Code (18) $\triangle 0 \varepsilon / \varepsilon m ; \Delta O \varepsilon / F \varepsilon, X F$

JC Category (19) uC-2000; uc-101, DDE/ER 